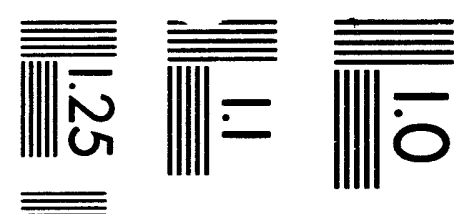

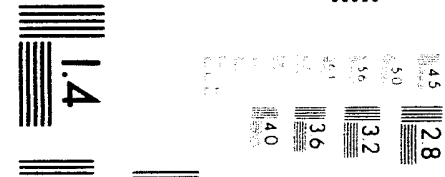

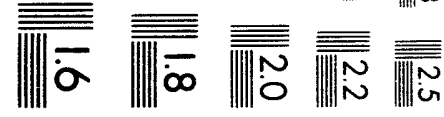



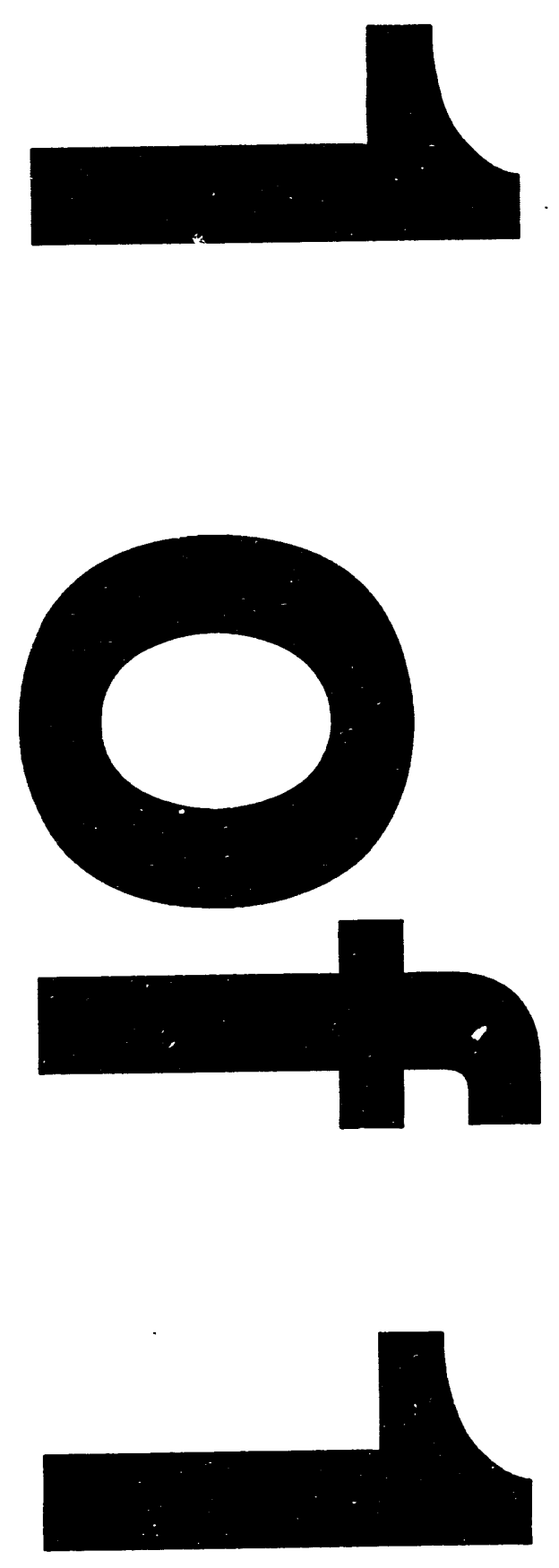


\section{ITP HANDFORD TYPE 40 PIN ELECTRICAL CONNECTOR} FAILURE ANALYSIS (U)

by

K. Imrich

Savannah River Site

Aiken, South Carolina 29808

UOE Contract No. DE-AC09-89SR18035

This paper was prepared in connection with work done under the above contract number with the U. S. Department of Energy. By acceptance of this paper, the publisher and/or recipient acknowledges the U. S. Government's right to retain a nonexclusive, royalty-free license in and to any copyright covering this paper, along with the right to reproduce and to authorize others to reproduce all or part of the copyrighted paper.

\section{MASTER}




\section{DISCLAIMER}

This report was prepared as an account of work sponsored by an agency of the United States Government. Neither the United States Government nor any agency thereof, nor any of their employees, makes any warranty, express or implied, or assumes any legal liability or responsibility for the accuracy, completeness, or usefulness of any information, apparatus, product, or process disclosed, or represents that its use would not infringe privately owned rights. Reference herein to any specific commercial product, process, or service by trade name, trademark, manufacturer, or otherwise does not necessarily constitute or imply its endorsement, recommendation, or favoring by the United States Government or any agency thereof. The views and opinions of authors expressed herein do not necessarily state or reflect those of the United States Government or any agency thereof.

This report has been reproduced directly from the best available copy.

Available to DOE and DOE contractors from the Office of Scientific and Technical Information, P. O. Box 62, Oak Ridge, TN 37831; prices available from (615) $576-8401$.

Available to the public from the National Technical Information Service, U. S. Department of Commerce, 5285 Port Royal Rd., Springfield, VA 22161 


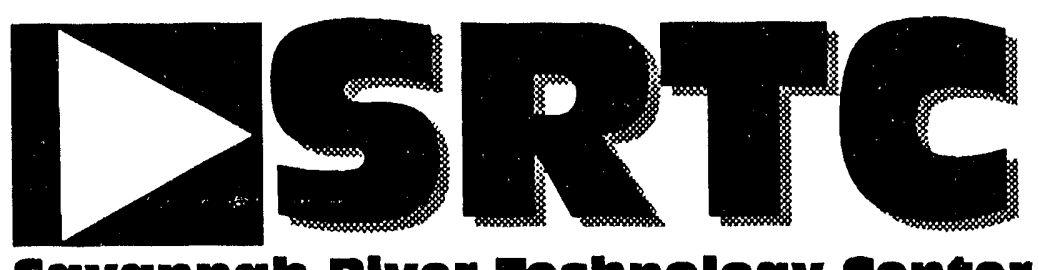

Savannah RIver Technology Center

October 15, 1993

SUBJECT DESCRIBERS

Hanford

Jumpers

Pins

Electrical

ITP

H-Area

To: S. B. Grimes, 241-119H

Retention: Lifetime ITP High Level Waste Engineering WSRC-TR-93-510

From:

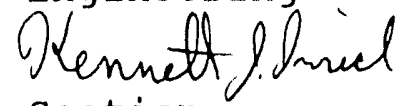

K. J. Imrich, 730-A

Materials Technology section

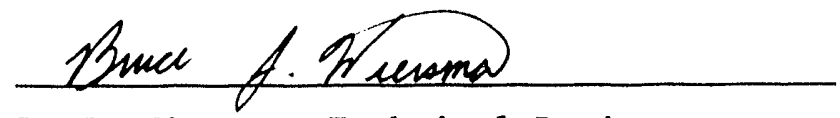

B. J. Wiersma, Technical Reviewer

Materials Technology Section

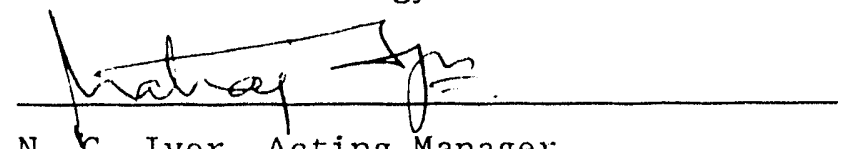

N. C. Iyer, Acting Manager

Mat. App1. \& Corr. Tech.

D. Thumer Rani

D. T. Rankin, Authorized Derivative Classifier

Materials Technology Section

ITP HANFORD TYPE 40 PIN ELECTRICAL CONNECTOR FAILURE ANALYSIS (U)

\section{Summary}

Corrosion products observed on the ITP Hanford Type 40 pin electrical connectors would be expected to adversely affect the power and control signals supplied to process equipment in the filter cell by the connectors. Corrosion products were consistent with those found on similar pins in DWPF. The recommendations based on the findings in this investigation are as follows:

1) Replace male and female rhodium plated pins with gold plated pins.

2) Replace the galvanized carbon steel spring on the male connector with a stainless steel spring. 
S: B. Grimes, $241-119 \mathrm{H}$

October 15, 1993

Page 3 of 7

WSRC-TR-93-510

electrical connector. The stains found on the Lexan blocks indicate that moisture was present and had drained out of the holes in the lexan plate. Use of a stainless steel spring would help eliminate this problem. Furthermore, capping the ends of the jumpers when they are removed will ensure that moisture and foreign material does not enter the jumper.

Pitting and corrosion of the rhodium/silver plated ITP 40 pin electrical connectors will result in degradation of current flow or signal quality due to excessive contact resistance. As corrosion of the connectors progresses total breakdown could result. Although some of the pins did not show significant signs of visible corrosion, corrosion of these pins is expected. The possibility of corrosive attack could be significantly reduced by using gold plated pins. plating quality of the gold pins, which were inspected in the MTS Metallurgical Lab and are used in DWPF, is superior to the rhodium plating on the pins currently installed in ITP. In addition to gold's excellent corrosion resistance and electrical properties other advantages of gold are: 1) widely used in the plating industry, 2) easily plated, 3) use of established industry accepted plating procedures (Military specifications) and 4) less expensive than rhodium.

The corrosion of the electrical connector pins from the DWPF canyon was resolved by replacing all the rhodium plated pins with gold plated pins. This recommendation was made by the DWPF Materials Committee and was based on evaluation the critical nature of the signals carried by the connector pins, safety and ALARA concerns, the expense of installing new pins following mercury and radioactive runs schedule, and difficulties involved in plating with rhodium. The issues in ITP are similar to those in DWPF. The plating specifications for the DWPF electrical connector pins are detailed in EES9201132.

\section{Recommendations}

The following are recommendations based on the results of this investigation:

1) Replace male and female rhodium plated pins with gold plated pins.

2) Replace the galvanized carbon steel spring on the male connector with a stainless steel spring.

3) Install protective caps over Hanford connectors when jumpers are removed. 
S. B. Grimes, $241-119 \mathrm{H}$

October 15, 1993

Page 3 of 7

WSRC-TR-93-510

electrical connector. The stains found on the Lexan blocks indicate that moisture was present and had drained out of the holes in the lexan plate. Use of a stainless steel spring would help eliminate this problem. Furthermore, capping the ends of the jumpers when they are removed will ensure that moisture and foreign material does not enter the jumper.

Pitting and corrosion of the rhodium/silver plated ITP 40 pin electrical connectors will result in degradation of current flow or signal quality due to excessive contact resistance. As corrosion of the connectors progresses total breakdown could result. Although some of the pins did not show significant signs of visible corrosion, corrosion of these pins is expected. The possibility of corrosive attack could be significantly reduced by using gold plated pins. Plating quality of the gold pins, which were inspected in the MTS Metallurgical Lab and are used in DWPF, is superior to the rhodium plating on the pins currently installed in ITP. In addition to gold's excellent corrosion resistance and electrical properties other advantages of gold are: 1) widely used in the plating industry, 2) easily plated, 3) use of established industry accepted plating procedures (Military specifications) and 4) less expensive than rhodium.

The corrosion of the electrical connector pins from the DWPF canyon was resolved by replacing all the rhodium plated pins with gold plated pins. This recommendation was made by the DWPF Materials Committee and was based on evaluation the critical nature of the signals carried by the connector pins, safety and ALARA concerns, the expense of installing new pins following mercury and radioactive runs, schedule, and difficulties involved in plating with rhodium. The plating specifications for the DWPF electrical connector pins are detailed in EES9201132.

\section{Recommendations}

The following are recommendations based on the results of this investigation:

1) Replace male and female rhodium plated pins with gold plated pins.

2) Replace the galvanized carbon steel spring on the male connector with a stainless steel spring.

3) Install protective caps over Hanford connectors when jumpers are removed. 
S. B. Grimes, 241-119H

October 15, 1993

Page 4 of 7

WSRC-TR-93-510

\section{References}

1. K. J. Imrich, corrosion of Hanford connector Pins From The DWPF Melter Jumpers (U), EES910214, Savannah River Site, Aiken, SC 29802 (November 1, 1991).

2. K. J. Imrich, plating Recommendation And Acceptance Criteria For DWPF Hanford-Type 40 PIN Electrical Connectors (U), EES920113, Savannah River Site, Aiken, SC 29802 (May 6, 1992). 
S. B. Grimes, 241-119H

October 15, 1993

Page 5 of 7

WSRC-TR-93-510

Figure 1

Photograph of ITP Filter Cell Male And Female 40 Pin

Electrical Connector (Negative No. EE-52646-A)

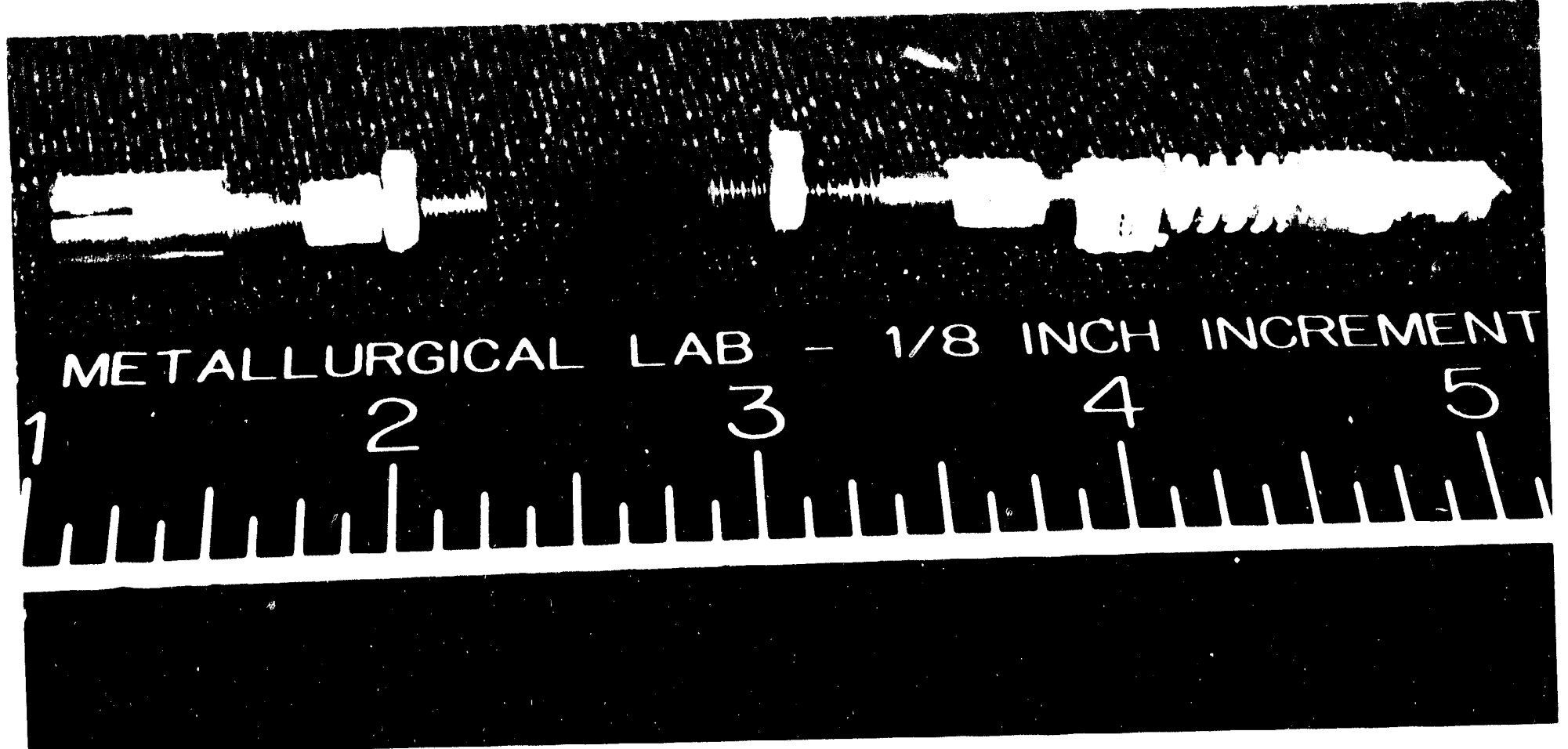


S. B. Grimes, 241-119H

October 15, 1993

Page 5 of 7

WSRC-TR-93-510

Figure 2

\section{Energy Dispersive X-Ray Analysis of Green And White Deposits on Male Pin No.36}
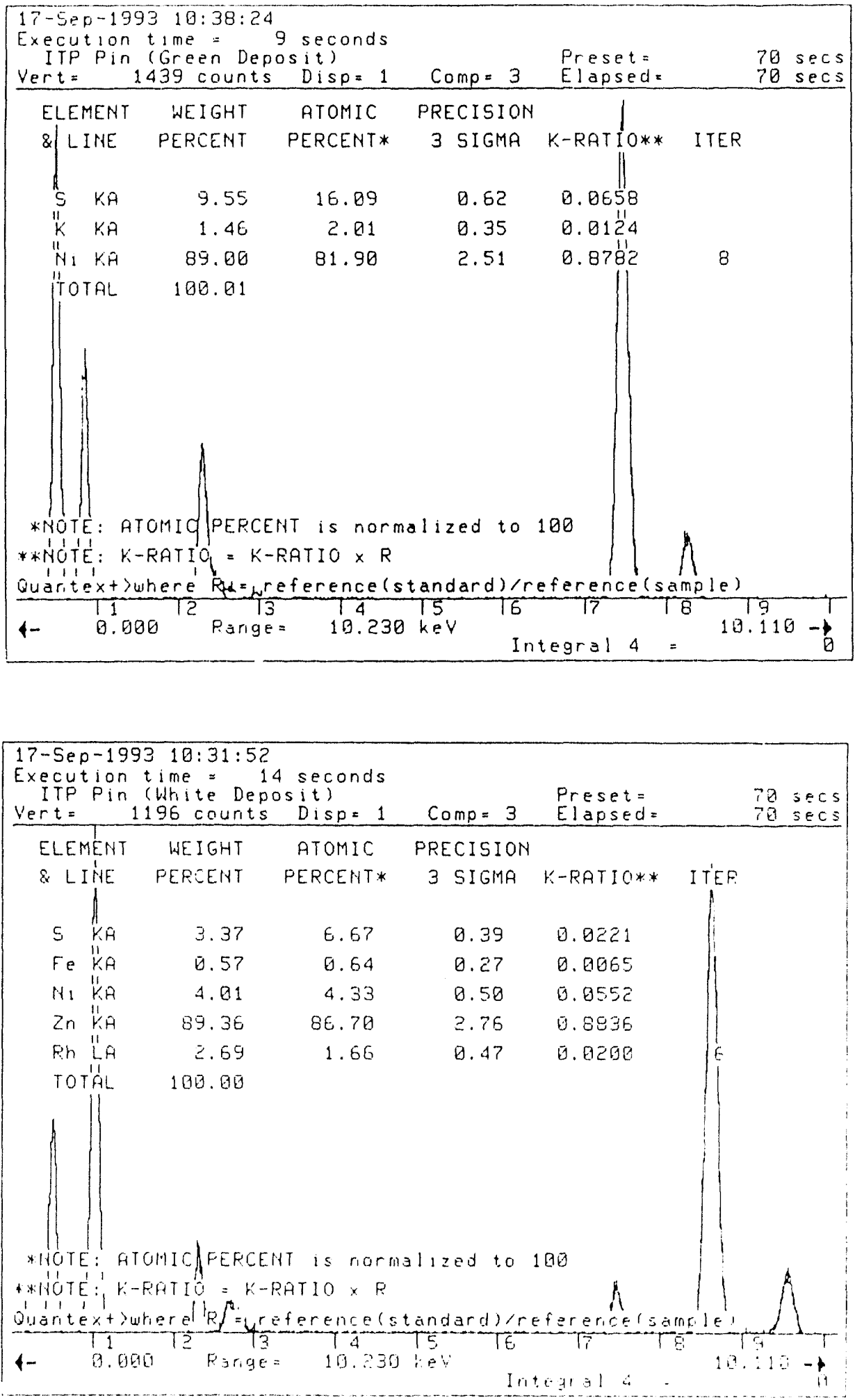

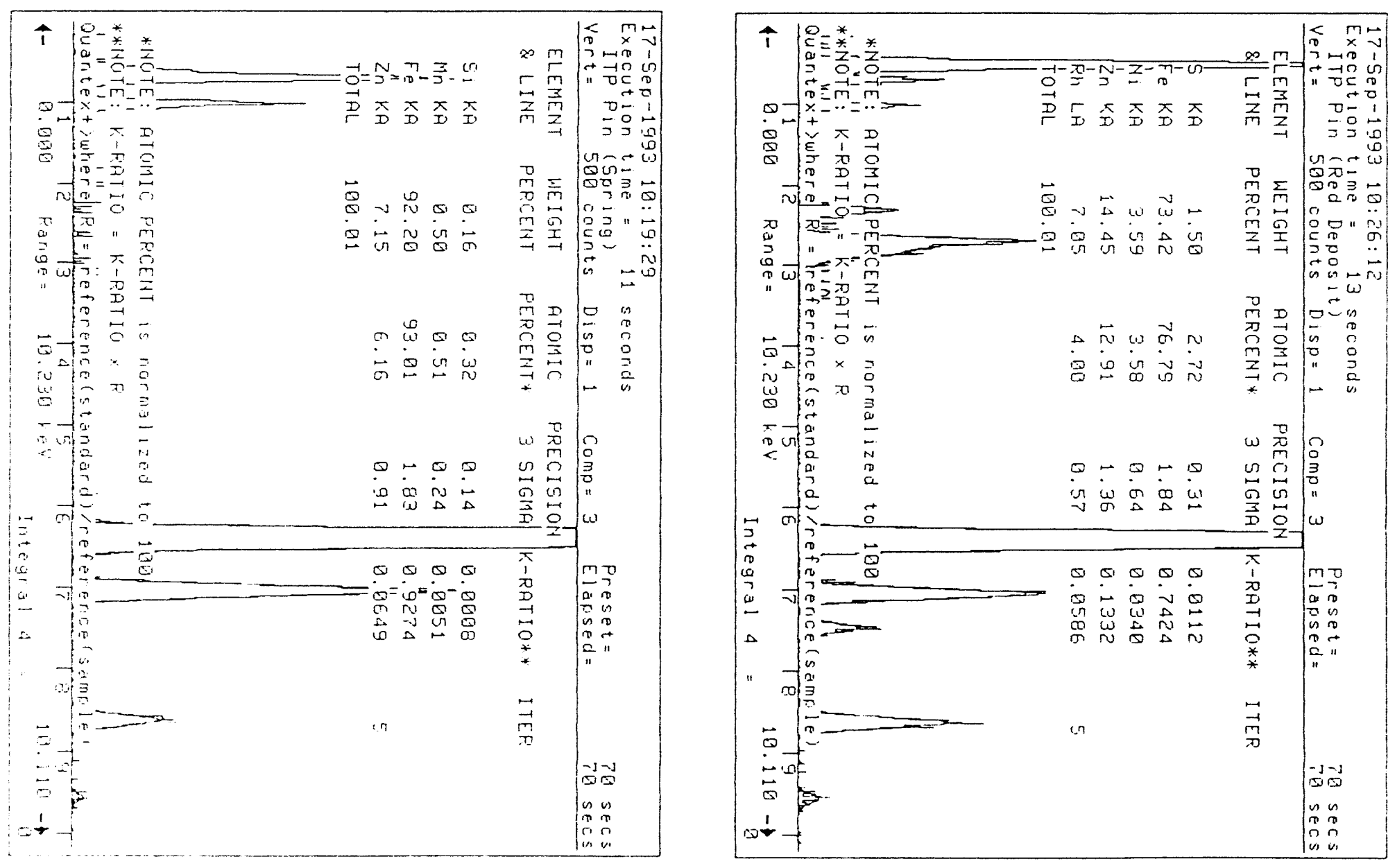

कृ

H.

1

要

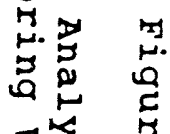

एक

क

مo

은

هั

皮品

定

का

造 0

5

茟 
CC: G. D. Thaxton, 241-119H

G. L. Cauthen, 241-119H

B. G. Croley, 241-120H

J. N. Brooke, 241-120H

W. B. Van Pelt, 241-152H

S. B. Grimes, 241-119H

S. A. Saunders, 241-102H

W. L. Tamosaitis, 773-A

J. D. Cohen, 730-A

T. L. Capeletti, 773-A

R. L. Bickford, 730-A

N. C. Iyer, 773-A

B. J. Wiersma, 773-A

TIM, 703-43A (4)

MTS Files, 773-A 

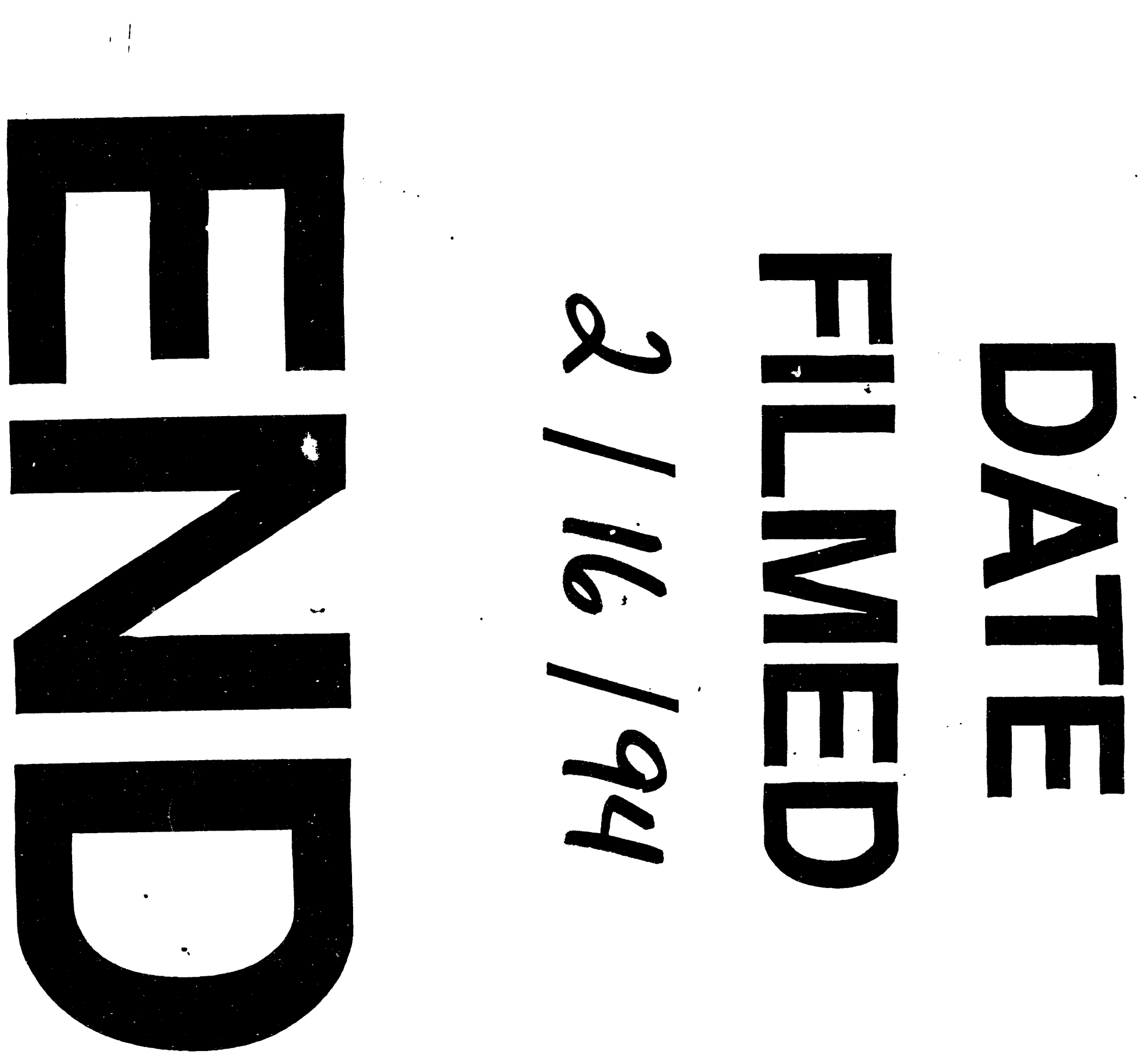